JURISPRUDENCIA 



\title{
ACTIVIDAD DEL TRIBUNAL CONSTITUCIONAL: RELACIÓN DE SENTENCIAS DICTADAS DURANTE EL TERCER CUATRIMESTRE DE 2020
}

\section{Activity of the Constitutional Court: List of rulings handed down during the third four-month period of 2020}

\author{
ÁREA DE DERECHO CONSTITUCIONAL \\ Universidad Carlos III de Madrid' \\ aelvira@der-pu.uc3m.es
}

Cómo citar/Citation

Elvira Perales, A. y Espinosa Díaz, A. (coords.) (2021).

Actividad del Tribunal Constitucional: relación de sentencias dictadas

durante el tercer cuatrimestre de 2020

Revista Española de Derecho Constitucional, 121, 199-219 doi: https://doi.org/10.18042/cepc/redc.121.07

\begin{abstract}
Durante el tercer cuatrimestre de 2020 se han dictado las sentencias que se reseñan a continuación:
\end{abstract}

A) Las sentencias dictadas en recursos de inconstitucionalidad han sido cuatro.

La Sentencia (en adelante STC) 131/2020, de 22 de septiembre, resuelve el recurso interpuesto por más de cincuenta senadores del Grupo Parlamentario Popular en el Senado respecto de la Ley 5/2019, de 4 de abril, de modificación de la Ley 12/2016, de 28 de julio, de reconocimiento y reparación de víctimas de vulneraciones de derechos humanos en el contexto de la violencia de motivación política en la Comunidad Autónoma del País Vasco entre 1978

1 La presente relación de sentencias ha sido elaborada por los profesores Elvira Perales y Espinosa Díaz (coords.); Gómez Lugo, Baamonde Gómez y López Rubio. 
y 1999. La Ley 5/2019, de 4 de abril, ya fue objeto de análisis de constitucionalidad en la reciente STC 83/2020, de 15 de julio, lo que acota la cuestión controvertida a los arts. primero a cuarto y a la disposición adicional única de la referida ley. En cuanto al primer bloque de impugnaciones, se rechazan con aplicación de la doctrina sentada en la mencionada resolución; y por lo que respecta a la disposición adicional única y su eventual invasión de la reserva de la función jurisdiccional de juzgar y hacer ejecutar lo juzgado (art. 117 $\mathrm{CE}$ ), considera el Tribunal que debe ser desestimada por falta de carga alegatoria por parte de los recurrentes. Finaliza aclarando que, en todo caso, el art. 7.1 de la Ley 12/2016, de 28 de julio, de reconocimiento y reparación de víctimas de vulneraciones de derechos humanos en el contexto de la violencia de motivación política en la Comunidad Autónoma del País Vasco entre 1978 y 1999, en la redacción dada por el art. tercero de la Ley 5/2019, y las menciones «a la más completa resolución de los expedientes», de los arts. 14.2 e) y 14.4, y a que «la Comisión [...] realizará un resumen de los hechos», del art. 14.8 de la Ley 12/2016, en la redacción dada por el art. cuarto de la Ley 5/2019, no son inconstitucionales siempre que sean interpretados en los términos de los apdos. a) y b) del fundamento jurídico 5. Formula un voto particular el magistrado D. Juan Antonio Xiol Ríos, quien discrepa de la mayoría en el fallo interpretativo y remite su argumentación a lo ya sostenido con ocasión de las SSTC 85/2018 y 83/2020. Por su parte, en su voto particular, la magistrada D. ${ }^{a}$ María Luisa Balaguer Callejón discrepa también de la interpretación conforme y se remite a lo expresado en sendos votos formulados a las SSTC $85 / 2018$ y $83 / 2020$, respectivamente.

La STC 134/2020, de 23 de septiembre, resuelve el recurso interpuesto por el Gobierno Vasco en relación con diversos preceptos del Real Decreto Ley 15/2018, de 5 de octubre, de medidas urgentes para la transición energética y la protección de los consumidores. Los preceptos impugnados regulan determinados aspectos de la ayuda directa denominada «bono social térmico» que se establece en el mencionado decreto ley. A juicio del órgano recurrente las disposiciones impugnadas vulneran la competencia exclusiva que el art. 10.12 de la Ley Orgánica 3/1979, de 18 de diciembre, de Estatuto de Autonomía para el País Vasco (EAPV), atribuye a la comunidad autónoma en materia de asistencia social y no se ajustan a la doctrina de este tribunal en materia de subvenciones y ayudas públicas. El Tribunal declara la inconstitucionalidad y nulidad de los incisos «mediante la concesión de un pago único anual» del apartado primero del art. 9; «junto con la información de los beneficiarios y los importes que les corresponden de acuerdo con lo previsto en los apartados anteriores» y «a partir de la información a que hace referencia el artículo 11» del apdo. segundo del art. 10 y «durante el primer trimestre 
del ańo» del apdo. tercero del art. 10, así como el art. 11 del Real Decreto Ley $15 / 2018$. También declara que la disposición adicional novena y la disposición final tercera del Real Decreto Ley 15/2018 son inconstitucionales en los términos de los fundamentos jurídicos 7 y 6 e), respectivamente.

La STC 148/2020, de 22 de octubre, resuelve el recurso interpuesto por el Defensor del Pueblo en relación con diversos preceptos de la Ley 9/2019, de 28 de marzo, de modificación de la Ley 4/1996, de 12 de julio, de caza en la Comunidad Autónoma de Castilla y León. En primer lugar, frente a las alegaciones de vulneración del procedimiento legislativo, el Tribunal concluye que la norma ha sido aprobada de conformidad con el procedimiento previsto en el bloque de constitucionalidad aplicable. En la medida en que el recurrente no ha identificado tampoco la fuente normativa de la que pueda deducirse la obligatoriedad, en el ordenamiento jurídico autonómico, de aportar unos concretos informes técnicos y jurídicos, que hubieran debido obrar en los antecedentes, descarta la violación del procedimiento legislativo. En cuanto al segundo motivo, sobre la alegación del recurrente de vulneración del art. 9.3 CE, la sentencia sigue lo señalado en la STC 134/2019 en relación con las denominadas leyes singulares. Sin embargo, concluye que el presente supuesto no reúne los rasgos propios de este tipo de normas. Por el contrario, se trata de una norma que nace con vocación de permanencia, que se proyecta hacia el futuro y que es susceptible de una pluralidad de aplicaciones. Por todo ello, desestima el recurso.

La STC 172/2020, de 19 de noviembre, resuelve el recurso interpuesto por más de cincuenta diputados de los grupos parlamentarios Socialista, La Izquierda Plural, Unión Progreso y Democracia y Mixto del Congreso de los Diputados en relación con diversos preceptos de la Ley Orgánica 4/2015, de 30 de marzo, de protección de la seguridad ciudadana. En sus fundamentos se parte de la distinción entre seguridad pública y seguridad ciudadana, esta, aun formando parte de la primera, es definida como «el estado en el que el conjunto de la ciudadanía goza de una situación de tranquilidad y estabilidad en la convivencia que le permite el libre y pacífico ejercicio de los derechos y libertades que la Constitución y la Ley les reconocen (STC 55/1990, de 28 de marzo, FJ 5), lo que se puede lograr a través de acciones preventivas y represivas» (FJ. 3 c), para después ir desgranando las distintas alegaciones efectuadas por los recurrentes, efectuando en cada uno de los casos un resumen de la previa doctrina tanto propia como del TEDH sobre ellos, para luego analizar si los preceptos enjuiciados son subsumibles o no en esta. A partir de esas premisas, en primer lugar, el Tribunal considera que los registros corporales del art. 20.2 LOPSC no resultan inconstitucionales. En segundo lugar, con respecto a las limitaciones al derecho de reunión del art. 36.2, interpreta 
que solo serán sancionables las conductas que, con ocasión de las reuniones ante los órganos legislativos, dañen de un modo intenso a personas o bienes (o entrañen un riesgo agravado de que se produzca ese resultado lesivo) u obstruyan sensiblemente el funcionamiento de estos, sin que puedan restringirse de concurrir esas circunstancias; mientras que, en lo referente a las sanciones previstas para los organizadores (art. 37), aclara:

[...] su responsabilidad se limitará, solo y exclusivamente, al hecho de que sean celebradas incumpliendo los requisitos previstos en la Ley reguladora del derecho de reunión, y no incluirá todo lo que suceda en esas reuniones o manifestaciones, ni todo lo que haga cada uno de los participantes en ellas. Los organizadores o promotores quedarán exonerados de responsabilidad por hechos ajenos si se prueba que no pudieron impedir la comisión de ciertos hechos a pesar de emplear la diligencia que era exigible; grado de diligencia que ha de ser interpretado, en estos casos, de forma que no dificulte en exceso el ejercicio del derecho de reunión (FJ 6).

Y con respecto a los participantes, solo cuando provoquen tales alteraciones sustanciales cuando les sean directamente imputables.

El Tribunal sí aprecia inconstitucionalidad en relación con el art. 36.23 LOPSC sobre que se sujete a la obtención de autorización administrativa previa el uso de imágenes o datos de las autoridades o miembros de las fuerzas y cuerpos de seguridad, puesto que significa una censura previa prohibida en virtud del art. 20.2 CE, lo que lleva a declarar inconstitucional el inciso «no autorizado» de dicho precepto, aclarando que el «uso» como conducta típica, dado que debe "poner en peligro [...] o en riesgo» alguno de los bienes jurídicos reseñados en el precepto, no se realiza con la mera captación o tenencia de «imágenes o datos personales y profesionales». Solo será sancionable, por tanto, el acto de publicar o difundir, sea cual sea el medio empleado, de modo que no bastará la mera captación no seguida de publicación o difusión de tales imágenes o datos. A lo que habrá que añadir que el «uso» a que alude el art. 36.23 CE es aquel que no cuenta con el consentimiento de los titulares de las imágenes o datos difundidos. Si la actividad de intervención únicamente juega en estos supuestos, con más razón el «riesgo» o "peligro» que configura el tipo infractor $e x$ art. 36.23 LOPSC es el que se presenta como próximo o concreto, descartando que pueda juzgarse realizada la conducta infractora cuando el «riesgo» o "peligro» es meramente abstracto o remoto. Por último, al referirse a la expresión "con respeto del derecho fundamental a la información», aclara que, en la aplicación del principio de proporcionalidad, se «abordará, al menos, (a) la comprobación de si las imágenes o los datos difundidos 
pertenecen a la vida privada o se relacionan con la actividad oficial de las autoridades o agentes; (b) el examen de qué relevancia pública tiene la difusión de esas imágenes o datos, atendiendo a las circunstancias fácticas y en particular a la presencia o no de un suficiente interés general en conocer esas imágenes o datos» (FJ 7. C.c.iii).

Por último, con respecto a la disposición final primera de la Ley Orgánica de protección de la seguridad ciudadana por la que se introduce una disposición adicional décima en la Ley Orgánica 4/2000, de 11 de enero, sobre derechos y libertades de los extranjeros en Espańa y su integración social, referida al régimen especial para Ceuta y Melilla de rechazo en frontera de los extranjeros que intenten entrar ilegalmente, se rechaza, en primer lugar, que existiera vulneración del procedimiento legislativo por inexistencia de conexión del texto enmendado. Con referencia a los aspectos sustantivos se sostiene el establecimiento de un régimen específico para Ceuta y Melilla debido a que en sus puestos fronterizos concurre la singularidad de su ubicación geográfica -única frontera exterior del espacio Schengen en tierras africanas, que también fue tomada en consideración por el TEDH, en sentencia de 13 de febrero de 2020, caso N.D. y N.T. c. España-. El Tribunal Constitucional incide, no obstante, en que deberá prestarse atención a cada caso, en particular, a los menores de edad o personas especialmente vulnerables por otras circunstancias.

Formula un voto particular discrepante la magistrada Sra. Balaguer.

B) Las sentencias dictadas en cuestiones de inconstitucionalidad han sido cinco.

La STC 101/2020, de 10 de septiembre, resuelve la cuestión planteada por la Sección Séptima de la Sala de lo Contencioso-Administrativo de la Audiencia Nacional respecto del art. único del Real Decreto Ley 2/2016, de 30 de septiembre, por el que se introducen medidas tributarias dirigidas a la reducción del déficit público, que añadió una nueva disposición adicional decimocuarta a la Ley 27/2014, de 27 de noviembre, del impuesto sobre sociedades. En ella se declara la pérdida sobrevenida de su objeto al haber declarado inconstitucional y nulo el precepto cuestionado en la STC 78/2020.

La STC 149/2020, de 22 de octubre, resuelve la cuestión planteada por la Sección Primera de la Sala de lo Contencioso-Administrativo del Tribunal Superior de Justicia de Castilla y León, en relación con el art. único, la disposición transitoria y la disposición derogatoria de la Ley 9/2019, de 28 de marzo, de modificación de la Ley 4/1996, de 12 de julio, de caza en la Comunidad Autónoma de Castilla y León. Esta misma cuestión constitucional fue 
abordada por el Tribunal en la STC 148/2020, que resolvió el recurso de inconstitucionalidad planteado por el Defensor del Pueblo contra la misma ley, por ello, el Tribunal se remite a lo decidido en el fundamento jurídico 5 de la citada sentencia y rechaza que la norma impugnada sea una ley singular, ya que no cumple con los rasgos especificados por la doctrina constitucional para este tipo de normas. También desestima la pretendida vulneración de los arts. 117.3 y 24.1 CE y el principio de separación de poderes invocada por el órgano proponente al sostener el auto de planteamiento que la norma impugnada otorga rango de ley a una materia que antes estaba regulada por reglamento, lo que impide que el Poder Judicial pueda controlar la determinación de las especies cinegéticas y cazables; la de los períodos y días hábiles para cazar y el resto de la regulación de la actividad cinegética. Sin embargo, el Tribunal no acepta estos argumentos porque:

[...] la ley puede regular cualquier materia, y esta posibilidad no puede verse restringida porque el reglamento que regulaba dicha materia se encuentre impugnado en vía judicial, pues como ya ha establecido este tribunal, del principio de exclusividad de jueces y magistrados en el ejercicio de la potestad jurisdiccional no puede inferirse la existencia de una correlativa prohibición impuesta al legislador, por la que se condicione su libertad de configuración para elegir el nivel de densidad normativa con que pretende regular una determinada materia (STC 139/2005, FJ 3) (STC 148/2020, FJ 5).

La STC 150/2020, de 22 de octubre, resuelve la cuestión planteada por la Sala de lo Contencioso-Administrativo del Tribunal Superior de Justicia de Navarra en relación con el art. 40 de la Ley Foral 7/2006, de 20 de junio, de defensa de los consumidores y usuarios. La norma en cuestión establece que las infracciones en la materia se calificarán de leves, graves y muy graves, en función de diez criterios distintos que enumera, pero sin especificar la relación que pueda haber entre estos requisitos y la calificación de la infracción en uno de los tres grados contemplados. Recordando la doctrina asentada en las sentencias 166/2012 y 10/2015, el Tribunal subraya que la concreción de si una determinada conducta, correctamente tipificada como infracción, constituye una infracción grave, menos grave o leve debe estar previamente predeterminada en la norma, no respetando el principio de taxatividad (derivado del art. 25.1 CE) una norma que traslade la calificación de las infracciones a un momento aplicativo posterior y externo a la previsión legal. Sobre esta base, la sentencia procede a declarar la inconstitucionalidad del artículo cuestionado.

La STC 151/2020, de 22 de octubre, resuelve la cuestión interna planteada por la Sala Primera del Tribunal Constitucional en el recurso de amparo 
1880-2018, respecto del último párrafo del art. 238 bis de la Ley de Enjuiciamiento Criminal, en la redacción dada por la Ley 13/2009, de 3 de noviembre, de reforma de la legislación procesal para la implantación de la nueva oficina judicial. La duda de constitucionalidad afecta a la disposición «[c]ontra el decreto del Secretario Judicial que resuelva el recurso de reposición no cabrá interponer recurso alguno", en la medida en que esta restricción en materia de régimen de recursos pueda suponer una vulneración del derecho fundamental a la tutela judicial efectiva sin indefensión que garantiza el art. 24.1 CE. En el auto de elevación de la autocuestión al Pleno se hace alusión a la doctrina fijada en las SSTC 58/2016, 72/2018 y 34/2019, que declararon inconstitucionales y nulos, respectivamente, el primer párrafo del art. 102 bis.2 de la Ley 29/1998, de 13 de julio, Reguladora de la Jurisdicción Contencioso-Administrativa (LJCA); el art. 188.1, párrafo primero, de la Ley 36/2011, de 10 de octubre, Reguladora de la Jurisdicción Social (LJS), y el párrafo tercero del art. 34.2 y el inciso «y tercero» del párrafo segundo y del párrafo cuarto del art. 35.2 de la Ley de Enjuiciamiento Civil (LEC), todos ellos en la redacción dada por la Ley 13/2009, de 3 de noviembre, de reforma de la legislación procesal para la implantación de la nueva oficina judicial. Por su parte, el Pleno, además de las resoluciones aludidas, tomará en consideración la más reciente STC 15/2020, y resolverá estimando la cuestión y declarando en consecuencia la nulidad del precepto objeto de análisis, señalando que en tanto el legislador no se pronuncie al respecto, el recurso judicial procedente frente al decreto del letrado de la Administración de justicia resolutivo de la reposición sea el directo de revisión.

La STC 171/2020, de 16 de noviembre, resuelve la cuestión planteada por el Juzgado de lo Contencioso-Administrativo n. 9 de Madrid respecto del apartado segundo de la disposición transitoria primera de la Ley 1/2018, de 22 de febrero, de coordinación de policías locales de la Comunidad de Madrid. Tal norma precisa que el acceso para cada una de las escalas de los cuerpos de policía local exigirá estar en posesión de la titulación requerida para los subgrupos correspondientes por la vigente legislación sobre función pública. El Tribunal constata la existencia de una inconstitucionalidad mediata de la norma al entrar en contradicción efectiva e insalvable con lo previsto en la disposición adicional vigésimo segunda de la Ley 30/1984, de 2 de agosto, de medidas para la reforma de la función pública, dictada válidamente al amparo del título sobre legislación básica en materia de función pública del art. 149.1.18 CE. En efecto, tal norma fija como excepción la promoción interna desde cuerpos o escalas del subgrupo $\mathrm{C} 2$ a cuerpos o escalas del subgrupo $\mathrm{C} 1$, pudiendo en tal caso sustituirse la exigencia de titulación por requisitos de antigüedad o formación específica. En consecuencia, se procede a declarar la inconstitucionalidad de la norma cuestionada. 
C) Los conflictos positivos de competencia han sido dos.

La STC 135/2020, de 23 de septiembre, resuelve el conflicto planteado por el Gobierno de la Nación, en relación con el Acuerdo Gov/90/2019, de 25 de junio, del Gobierno de la Generalitat de Cataluña, por el que se aprueba el plan estratégico de acción exterior y de relaciones con la Unión Europea 2019-2022 y se acuerda su envío al Parlamento de Cataluńa. El Tribunal recuerda su doctrina asentada en la Sentencia 228/2016, que establece que la acción exterior de las comunidades autónomas ha de venir limitada a la que derive directamente de sus competencias, con respeto a la competencia del Estado en materia de relaciones exteriores (art. 149.1.3 $\mathrm{CE})$, y no pudiendo significar en ningún caso la consideración de Cataluña como un sujeto de derecho internacional; sobre esta base, el Tribunal anula múltiples puntos del plan estratégico por contravenir tales límites, y entre ellos los relativos a «la consolidación y fortalecimiento de vínculos con el cuerpo diplomático y consular»; "la participación proactiva en los foros multilaterales de máximo interés»; "la puesta en marcha del Consejo de Diplomacia Pública de Cataluña»; el impulso a «una acción exterior integral hacia el continente africano»; la elaboración de un plan América Latina y Caribe»; «la Identificación de oportunidades de colaboración con otros países del mundo"; "la Intensificación de la incidencia en la agenda internacional de derechos humanos»; «el incremento de las relaciones con las organizaciones de ámbito internacional de defensa de los derechos civiles y políticos»; «[c]ontribución a la solución pacífica, dialogada, justa y duradera de los conflictos armados, incluidas las situaciones de extremismo violento", y el «apoyo a las poblaciones en los procesos de descolonización, autodeterminación y transiciones democráticas». En todos estos campos, indica el Tribunal, se produce «una afectación negativa del ámbito reservado al Estado, cuyas competencias en materia de política exterior quedarían aquí, cuando menos, perturbadas y en entredicho». La sentencia también declara inconstitucionales y nulos varios puntos del plan por invadir otros títulos competenciales del Estado. Así ocurre, por ejemplo, con el punto sobre el denominado corredor mediterráneo, los servicios regionales ferroviarios de altas prestaciones para viajeros entre Cataluña y Occitania y la red transeuropea de transporte, por afectar a las competencias estatales en materia de transporte (art. 149.1.21 CE) y sobre obras públicas de interés general (art. 149.1.24 CE); con el punto sobre internacionalización y ordenación del sistema portuario catalán e internacionalización de los aeropuertos de Cataluña, por afectar a la competencia estatal exclusiva en materia de puertos y aeropuertos de interés general (art. 149.1.20 CE), o con el punto relativo al 
despliegue de infraestructuras digitales, invasor de la competencia estatal en materia de telecomunicaciones y de régimen general de comunicaciones (149.1.21 CE). De algunos otros puntos, relatados en el fallo de la sentencia, se realiza una interpretación conforme con la Constitución.

Formulan un voto particular los magistrados Sr. Juan Antonio Xiol Ríos y Sra. María Luisa Balaguer Callejón. En su voto, en rigor concurrente dado su apoyo a la sentencia, remiten en esencia a los argumentos reflejados por el Sr. Xiol Ríos en su voto particular a la Sentencia 228/2016.

La STC 152/2020, de 22 de octubre, resuelve el conflicto planteado por la Generalitat de Cataluńa respecto del escrito de 3 de marzo de 2020 de la directora de Competencia de la Comisión Nacional de los Mercados y la Competencia, por el que se requiere a la Autoridad Catalana de la Competencia la remisión del expediente «Campańa de Consumo Estratégico». El Tribunal parte de su doctrina establecida en la Sentencia 208/1999, la cual seńala que la materia de defensa de la competencia se incardina en el título sobre coordinación de la planificación económica general (art. 149.1.13 CE). A partir de ahí, correspondería al Estado toda actividad, normativa o ejecutiva, frente a prácticas que puedan alterar la libre competencia en un ámbito supracomunitario o en el conjunto del mercado nacional, pudiendo solo intervenir las comunidades autónomas frente a aquellas acciones cuya repercusión no superara el ámbito autonómico. Respecto del expediente en cuestión, el Tribunal constata su alcance supracomunitario, en tanto que supuso un llamamiento a los consumidores catalanes, tanto públicos como privados, a contratar con proveedores «estratégicos» catalanes, en perjuicio de operadores de ámbito nacional o, incluso, multinacional. Con ello, se subraya, se intenta provocar la fragmentación del mercado nacional. En consecuencia, se constata la competencia estatal, desestimándose el conflicto.

D) El número de recursos de amparo ha sido de 82.

De conformidad con el fallo, han resultado estimatorias: 75, parcialmente estimatorias: 2. De ambas han tenido el carácter de devolutivas: 68. El número de sentencias desestimatorias ha sido: 5 .

La STC 161/2020, de 16 de noviembre, resuelve la extinción del recurso por pérdida sobrevenida del objeto al haberse anulado en revisión las resoluciones impugnadas.

La STC 195/2020, de 17 de diciembre, inadmite el recurso por carencia de legitimidad procesal, en línea con lo afirmado en la STC 39/2020.

Los actores se clasifican de la siguiente forma: 
Particulares: 31 .

Entidades mercantiles: SL 41.

Junta de Extremadura: 6.

Diputados: 3.

Universidad privada: 1 .

Las SSTC 120, 124, 128 y 129/2020, todas de 21 de septiembre, y $168 / 2020$, de 16 de noviembre, estiman todas una vulneración del derecho de igualdad ante la ley, así como discriminación por razón de sexo en el mismo sentido de la STC 79/20, al considerar

que la fórmula de cómputo de la reducción de la jornada de trabajo por motivos de guarda legal para el cuidado de hijos menores (i) vulnera el derecho a la igualdad, ya que siendo comparable la situación subjetiva de quienes hacen un servicio de guardia de idéntica duración, entonces carece de justificación objetiva y razonable que se genere un descanso retribuido diferenciado, derivado de la realización de unas guardias que, aun en número menor por haber una reducción de jornada por el cuidado de hijos menores, son de la misma duración que para el resto de los trabajadores; y (ii) vulnera la prohibición de discriminación indirecta por razón de sexo

por afectar en mayor medida a mujeres.

La STC 191/2020, de 17 de diciembre, analiza si la exclusión de becas para alumnos de universidades privadas establecida por una orden de la Consellería de Educación de la Comunidad Valenciana vulnera el derecho a la igualdad en relación con la libertad de creación de centros docentes y el derecho a la educación al entender que carece de una justificación objetiva y razonable y no contar con apoyo en la legislación valenciana, que no establece diferencias entre universidades públicas y privadas, además de que los derechos educativos de los estudiantes no pueden entenderse «sin la referencia a las instituciones educativas en las que cursan sus estudios». Se formulan dos votos particulares discrepantes, el primero firmado por el Sr. Xiol y la Sra. Balaguer y el segundo, por el Sr. Conde-Pumpido.

La STC 180/2020, de 14 de diciembre, analiza un supuesto en el que el recurrente no había tenido conocimiento de los documentos por los que el Ministerio Fiscal solicitaba la prisión provisional; por otra parte, si bien el proceso había sido declarado secreto en algunos momentos, no lo era al solicitar esa medida cautelar, por lo que no hubo igualdad de armas. Se vulneró, por tanto, el derecho de libertad personal, pues la prisión se decretó sin seguir el procedimiento establecido y no se respetaron las garantías mínimas. 
En la STC 181/2020, de 14 de diciembre, se considera que, una vez la detenida ha manifestado su derecho a no declarar, preguntar si se autoriza una entrada domiciliaria no vulnera el art. 17.3 CE, pues busca preservar el derecho del art. 18.2 CE. Sin embargo, la información que la policía facilitó a la recurrente sobre los hechos y razones para su detención no fue suficiente, por lo que se produjo la vulneración del art. 17.3 CE. Ante la interposición de un habeas corpus, el juez llevó a cabo una inadmisión a limine, a pesar de que se daban los requisitos para su admisión, por lo que igualmente se ha visto vulnerado el art. 17.4 CE.

La libertad de expresión en relación con unas expresiones consideradas como delito de ultraje a la bandera es el objeto de la STC 190/2020, de 15 de diciembre. En ella el Tribunal repasa su propia doctrina y la del TEDH respecto a casos similares, para llegar a la conclusión de que las expresiones empleadas no tenían vinculación con las reivindicaciones laborales a las que supuestamente se vinculaban y que contaron con la reprobación del resto de participantes en estas, lo cual lleva a considerar que las expresiones proferidas constituyeron una extralimitación al resultar innecesarias y no contribuir a la creación de una opinión pública libre. Asimismo, estima que la pena impuesta resulta proporcionada. Formulan cuatro votos particulares discrepantes los magistrados Sra. Roca, Sr. Ollero, conjuntamente el Sr. Xiol y la Sra. Balaguer, y, finalmente, el Sr. Conde Pumpido, lo que muestra la profunda controversia suscitada en el seno del Tribunal.

La STC 192/2020, de 17 de diciembre, analiza un conflicto entre la libertad de expresión y la libertad religiosa y de culto al haber realizado el recurrente manifestaciones en favor del aborto durante la celebración de una misa. El Tribunal considera que el lugar y el momento elegidos vulneraban la libertad religiosa de los congregados. De igual forma, rechaza que se hubiera producido una interpretación analógica de la tipificación prevista en el Código Penal (arts. 523 y 514.4), al considerar que los hechos sí tenían cabida en los tipos penales aplicados. Formulan sendos votos particulares discrepantes, por un lado, el Sr. Xiol y la Sra. Balaguer, conjuntamente, por otro, el Sr. Conde-Pumpido.

La STC 173/2020, de 19 de noviembre, desestima una vulneración del derecho al ejercicio de funciones representativas. En ella, con respecto al acuerdo de la Mesa por el que se pospone una sesión ordinaria a otra fecha, el Tribunal recuerda que, «con independencia de la modalidad de recurso de amparo de que se trate, no cabe interponer un recurso de amparo buscando un pronunciamiento declarativo o abstracto (STC 189/1993, de 14 de junio, FJ 2), ni cabe invocar una vulneración inconcreta». En consecuencia, desestima la queja al considerar: 
Al no haberse solicitado la reconsideración, este tribunal no puede sino entender, a falta de otros razonamientos, máxime cuando la vulneración denunciada es genérica y se hace recaer sobre la falta de motivación o justificación alguna acerca del traslado de la fecha de la sesión, que la decisión de la mesa afecta exclusivamente a una cuestión meramente organizativa, relativa al calendario y a la organización del trabajo parlamentario que, según el art. 38 RPC, no es susceptible de reconsideración.

Por otro lado, la sentencia descarta que la omisión de la convocatoria de varias sesiones plenarias haya vulnerado el art. 23.2 CE, pues los recurrentes en la demanda no especifican qué iniciativas concretas se vieron limitadas por dicha omisión, y manifiesta que esa concreción resulta necesaria para que, a la vista del contenido de las iniciativas, el Tribunal pueda resolver sobre la vulneración del derecho invocado.

Las SSTC 193 y 194/2020, ambas de 17 de diciembre, analizan una supuesta vulneración del derecho al ejercicio de cargo público y a la presunción de inocencia, por la declaración de la suspensión como diputados de los recurrentes. En ambas se aplica la doctrina expuesta en la STC 97/2020, a la que remiten, y que conlleva a la desestimación de los recursos.

La sentencias concernientes al derecho a la tutela judicial efectiva pueden clasificarse de la siguiente forma:

a) Comunicación procesal: SSTC 103, 104 y 105/2020, todas de 21 de septiembre procesal, en las que se sigue la doctrina de las SSTC 6/2019 y 47/2019, al igual que en las SSTC 110 a 118/2020, todas de 21 de septiembre, 121, 122 y 123/2020, todas de 21 de septiembre, 126 y 127/2020, ambas de 21 de septiembre, 130/2020, de 21 de septiembre, 133/2020, de 23 de septiembre, a la que formula un voto particular discrepante el Sr. Conde-Pumpido por considerar que no tenía que haberse admitido el recurso al no haber agotado la vía judicial previa, SSTC 138 y 139/2020, ambas de 6 de octubre, 146/2020, de 19 de octubre, 156, 157, 158, 159/2020, todas de 4 de noviembre, 169 y 170/2020, ambas de 16 de noviembre, 174, 175 y 176/2020, todas de 30 de noviembre, 183, 184, 185, 186, 188 y 189/2020, todas de 14 de diciembre. Y SSTC 119/2020, de 21 de septiembre, y 167/2020, de 16 de noviembre; en ambas se aprecia falta de diligencia para obtener una notificación personal conforme a reiterada jurisprudencia, lo que afecta igualmente a la posibilidad de que la parte sea oída en el proceso. Y STC 125/2020, de 21 de septiembre, en la que se considera que el juzgado no extremó su diligencia para averiguar el 
domicilio del deudor ejecutado; en similar sentido, STC 187/2010, de 14 de diciembre.

b) Motivación: STC 140/2020, de 6 de octubre, en ella se sigue la interpretación de la STC 31/2019, en el sentido no solo de declarar vulneración del derecho a la tutela judicial por falta de motivación, sino también por no haber respetado el principio de primacía del derecho de la Unión Europea.

c) Acceso a la justicia y motivación: en la STC 155/2020, de 4 de noviembre, el recurso es estimado por habérsele negado la legitimación activa a la actora en aplicación de la doctrina de la STC 80/20.

d) Acceso a la jurisdicción: en la STC 141/2020, de 19 de octubre, considera la parte recurrente que las resoluciones judiciales impugnadas, haciendo uso de una interpretación rigorista de la ley, impiden el control judicial del embargo acordado por la Administración tributaria en los términos previstos en el art. 81.8 de la Ley General Tributaria y el art. 614 bis LECrim, lo que conduce a que estime el Tribunal sus pretensiones al entender que las facultades atribuidas a la Administración tributaria para la adopción de medidas cautelares no excluyen el debido control judicial a posteriori de tales medidas.

Las SSTC 145/2020, de 19 de octubre, y 162/2020, de 16 de noviembre, siguen la doctrina de las SSTC 15 y 17/2020. Las SSTC 163 y 164/2020, ambas de 16 de noviembre, 179/2020, de 14 de diciembre, y 182/2020, de 14 de diciembre, son estimatorias al impedir las resoluciones impugnadas la revisión judicial al aplicar el precepto legal anulado por la STC 151/2020, de 22 de octubre.

e) Derecho a la tutela judicial efectiva sin indefensión: STC 143/2020, de 19 de octubre, que estima el recurso al considerar que la argumentación de la Audiencia relativa a la necesidad de plantear recurso extraordinario por infracción procesal junto con el de casación resulta irrazonable, al ser este último manifiestamente improcedente en el caso.

f) Acceso a los recursos: STC102/2020, de 21 de septiembre; en ella, en primer lugar, el Tribunal desestima la queja relativa a la vulneración del art. 14, que hubiese requerido la interposición de una cuestión interna de inconstitucionalidad, dado que la posible vulneración provenía de la ley, al considerar que los supuestos comparados no son comparables y, por tanto, no es aplicable la doctrina del Tribunal. Por otro lado, se considera vulnerado el derecho a la tutela judicial efectiva porque la decisión de inadmisión del incidente de nulidad de actuaciones se hizo con una respuesta estereotipada, sin suficiente motivación. 
Las SSTC 106, 107, 108 y 109/2020, todas de 21 de septiembre, la STC 136/2020, de 6 de octubre, con voto particular del Sr. Enríquez, remitiendo al que formulara a la STC 99/2020, y la STC 144/2020, de 19 de octubre, están todas en línea con la doctrina de la STC 99/2020, contando las SS 107, 108 y 144 con sendos votos particulares de los magistrados Sr. Xiol, remitiendo en ambos casos al formulado a la STC 128/2018, y Sr. Enríquez, que remite, a su vez, al que formuló en la citada STC 99/2020.

g) Derecho a la presunción de inocencia y a la igualdad: SSTC 137/2020, de 6 de octubre, 153 y 154/2020, ambas de 4 de noviembre, y $166 / 2020$, de 16 de noviembre, y 177/2020, de 14 de diciembre, en las que se sigue lo establecido en las SSTC 85 y 125/2919.

h) Resolución fundada en derecho: STC 160/2020, de 16 de noviembre, en la que constata que la sentencia incurrió en error manifiesto sobre los presupuestos fácticos en que basó su resolución, pues las notificaciones de liquidación realizadas por la Administración resultaron manifiestamente defectuosas desde la óptica de la debida diligencia. Subrayando que la validez atribuida por la Audiencia a tales notificaciones constituyó la ratio decidendi de su sentencia, el Tribunal estima el recurso.

Derecho a la defensa en relación con libertad de expresión: STC 142/2020, de 19 de octubre, en la que el Tribunal considera que las afirmaciones realizadas por un abogado respecto al representante del Ministerio Fiscal deben quedar protegidas por el derecho de defensa en conexión con la libertad de expresión, al entender que en el caso no se habían utilizado insultos y que las expresiones eran deliberadamente confusas, se produjeron en el contexto estrictamente forense (por tanto, sin publicidad), en un clima de enfrentamiento entre ambas partes, y la pena efectivamente impuesta por tales expresiones resultaba excesiva, si bien el Tribunal señala que nada impide el empleo de una vía alternativa a la penal (disciplinaria).

j) Derecho a la tutela judicial efectiva y a un proceso con todas las garantías: STC 147/2020, de 19 de octubre, en la que se analiza la vulneración de los derechos a la tutela judicial efectiva y a un proceso con todas las garantías (art. $24 \mathrm{CE}$ ), en conexión con los derechos a la libertad personal (art. $17 \mathrm{CE}$ ) y a la libertad de residencia y circulación (art. $19 \mathrm{CE}$ ). Se impugnan por la parte actora las resoluciones judiciales emitidas por la Audiencia Nacional en las que se acepta como soporte de la demanda de extradición un escrito de acusación de la Fiscalía colombiana carente de refrendo judicial. Tras un análisis 
del canon interpretativo europeo, así como de la posición institucional que ocupa la Fiscalía General de la Nación en el sistema judicial colombiano, el Tribunal termina por concluir que no puede derivarse una equiparación entre el escrito de acusación de esta y un auto de prisión sin provocar una sustancial distorsión del sistema de garantías de la libertad, tal y como comúnmente se concibe en el art. 17.1 CE, el art. 6 de la Carta de derechos fundamentales de la Unión Europea y el art. 5 del Convenio europeo de derechos humanos. En consecuencia, estima el amparo.

En el caso de la STC 165/2020, de 16 de noviembre, se aprecia vulneración del derecho a la tutela judicial efectiva sin indefensión y al principio de igualdad de armas procesales, producida como consecuencia de que la Administración sanitaria no aportara la documentación pertinente cuando por ley está obligada a garantizar la custodia y conservación de la documentación clínica del paciente en condiciones que garanticen su correcto mantenimiento y seguridad.

k) Derecho a un proceso con todas las garantías: en la STC 132/2020, de 23 de septiembre, se aborda una extradición que no respeta el contenido absoluto del derecho al no constar la renuncia inequívoca del acusado a estar presente en el juicio penal que lo condenó. Considera el recurrente que la Audiencia Nacional, al posibilitar su entrega incondicionada a Colombia, aplicó la doctrina sentada en la STC 26/2014 (caso Melloni), relativa a un supuesto de ejecución de una orden europea de detención y entrega, no procedente en su caso, lo que lleva a que el Tribunal efectúe un análisis comparado entre la extradición y la euroorden, lo que le permite concluir que ambos institutos jurídicos coinciden en su finalidad, aunque difieren en su naturaleza por estar basados en principios jurídicos diversos (la extradición, en la simple cooperación, y la euroorden, en la cooperación reforzada que se traduce en el reconocimiento mutuo), así como en el procedimiento tendente a la entrega de la persona reclamada por las autoridades de otro Estado. Ello implica que los órganos judiciales deberán modular el rigor de su control, siendo más exigentes en el primer caso. Concluye estimando el amparo al considerar que la Audiencia Nacional no ponderó adecuadamente las exigencias constitucionales en materia de extradición cuando el juicio ha tenido lugar en ausencia del recurrente. Formula un voto particular discrepante el magistrado D. Andrés Ollero, quien considera erróneo trazar una distinción entre las exigencias constitucionales relativas a la extradición y la aplicación de la euroorden, respectivamente. Remite en su argumentación a lo expresado en su voto particular a la STC 26/2014. 
1) Derecho a la tutela judicial efectiva en relación con los derechos a la propia imagen y a la protección integral de los hijos: en la STC 178/2020, de 14 de diciembre, se estima vulnerado el derecho a la tutela judicial efectiva porque, en un proceso de filiación que supuso el cambio de orden de apellidos de la menor, el Tribunal no tuvo en cuenta el interés superior del menor, debiendo haber prescindido del óbice procesal detectado. Por otro lado, la jurisdicción ordinaria optó por poner en primer lugar el apellido del padre sin haber valorado el interés de la menor afectada.

\begin{tabular}{lcccc}
\hline \multicolumn{1}{c}{ Órgano } & Sentencia & Auto & Providencia & Decreto \\
\hline Tribunal Supremo & 4 & 1 & 2 & \\
TSJ & 5 & & 6 & \\
Audiencia Nacional & 3 & 2 & & \\
Audiencia Provincial & 2 & 4 & 1 & 1 \\
Juzgado de $1 .^{\text {a }}$ Instancia & & 37 & 5 & \\
Juzgado de lo Penal & & & & \\
Juzgado de lo Social & 1 & 1 & & \\
Juzgado de lo Contencioso-Administrativo & 1 & & & 2 \\
Juzgado de Vigilancia Penitenciaria & & 1 & & \\
\hline
\end{tabular}

Tres resoluciones de Mesa de Parlamento.

En el período los magistrados que han formulado votos particulares han sido los siguientes:

— Sra. Balaguer Callejón: 5.

- Sr. Conde-Pumpido Tourón: 4.

- Sr. Enríquez Sancho: 4.

- Sr. Ollero Tassara: 2.

- Sra. Roca Trías: 1.

— Sr. Xiol Ríos: 8. 


\section{RELACIÓN DE SENTENCIAS DEL TRIBUNAL CONSTITUCIONAL TERCER CUATRIMESTRE DE 2020 \\ Por procedimientos}

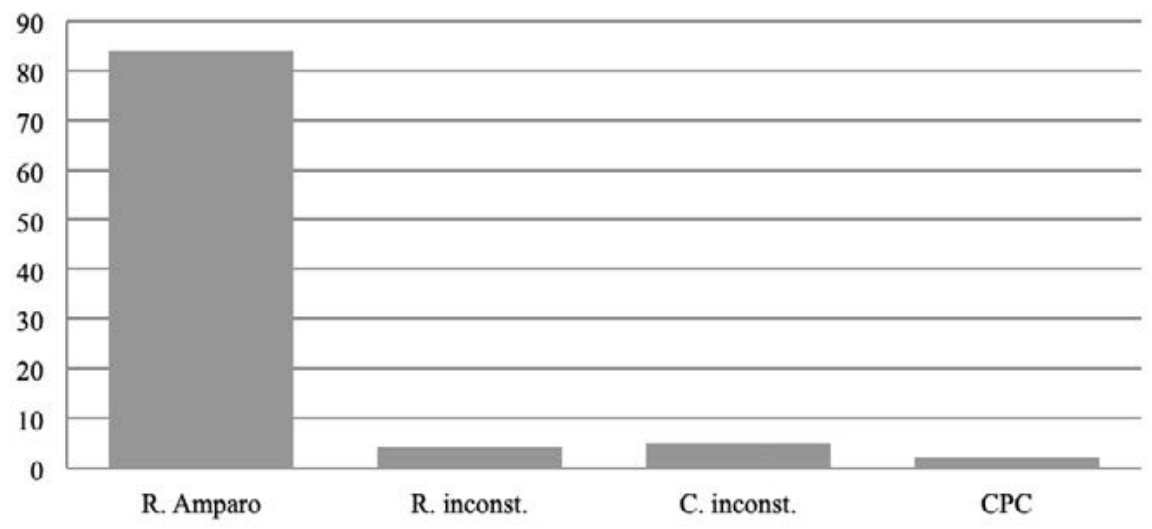

\section{RECURSOS DE AMPARO. SEGÚN EL CONTENIDO. TERCER CUATRIMESTRE DE 2020}

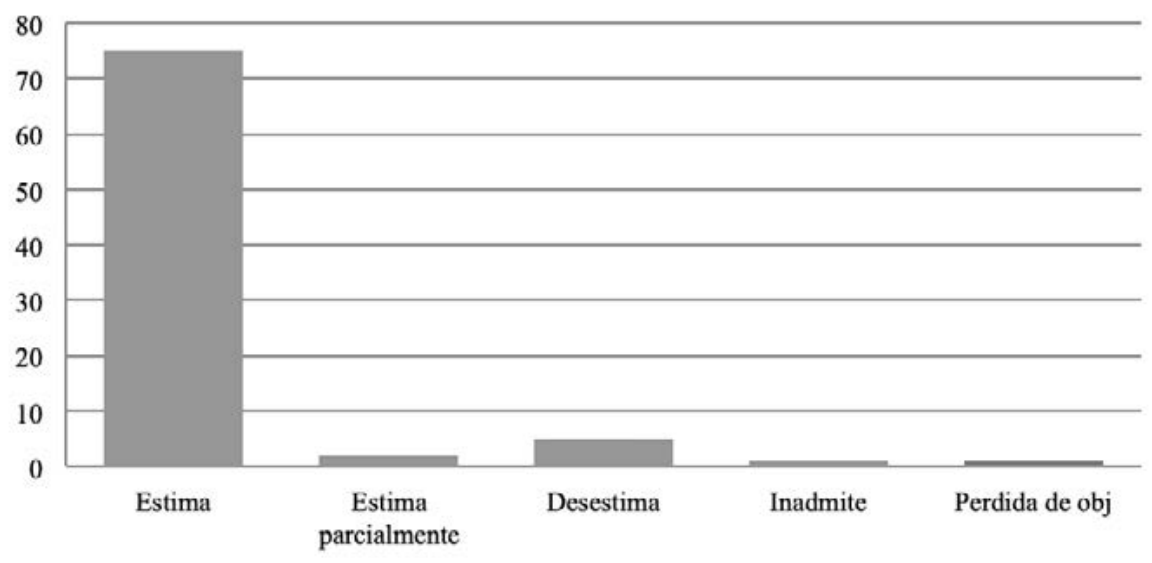


RECURSO DE AMPARO. DERECHO FUNDAMENTAL ALEGADO. TERCER CUATRIMESTRE DE 2020

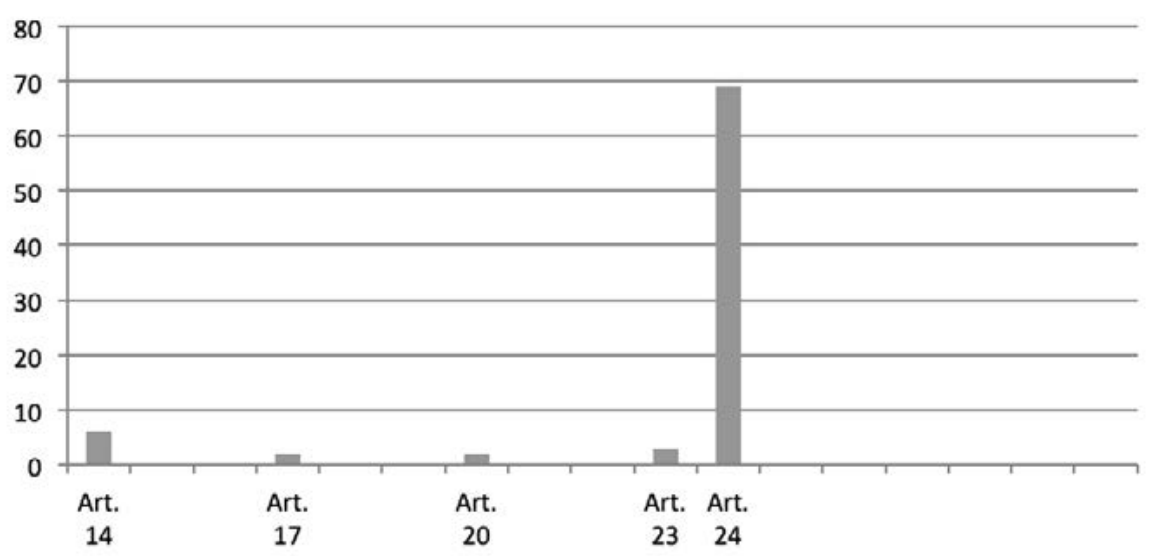

RECURSOS DE AMPARO. ÓRGANO JUDICIAL QUE DICTA LA RESOLUCIÓN RECURRIDA. TERCER CUATRIMESTRE DE 2020

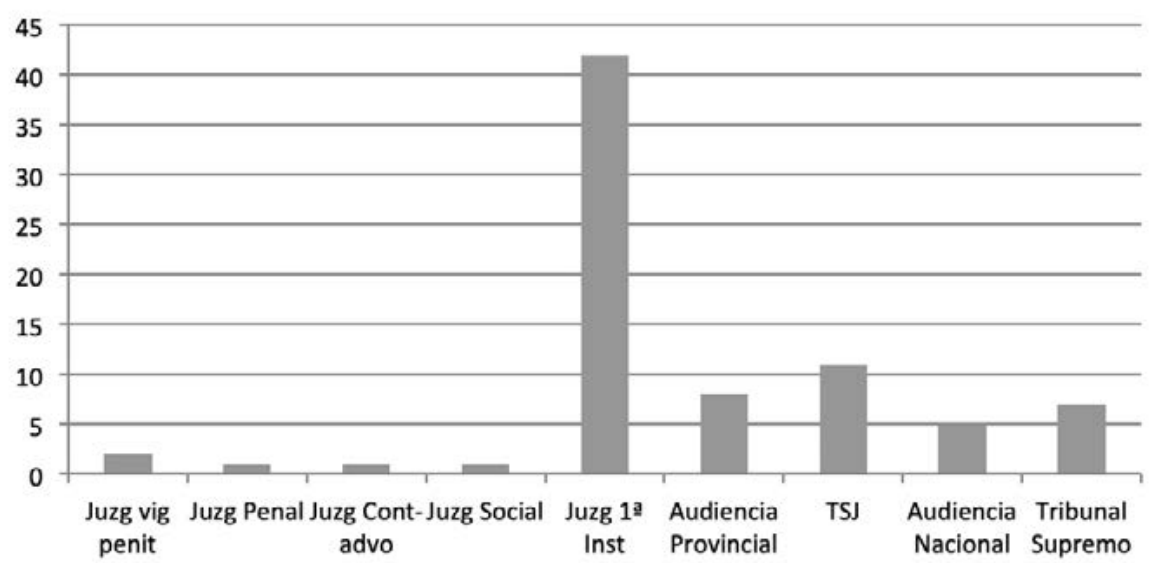




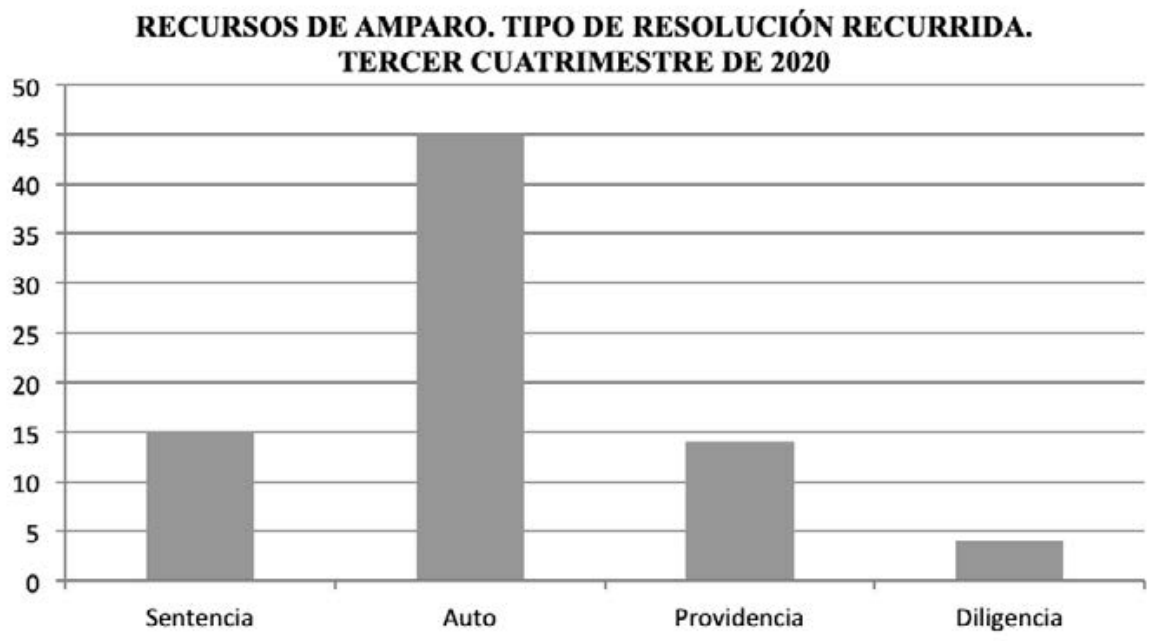

\section{RELACIÓN DE SENTENCIAS DEL TRIBUNAL CONSTITUCIONAL AÑ̃ 2020 \\ Por procedimientos}

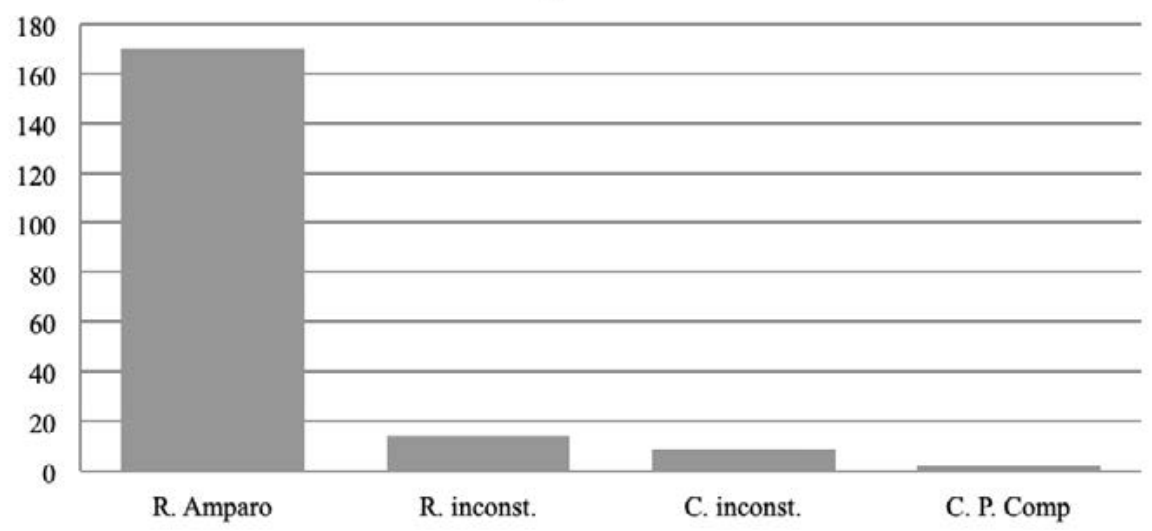


RECURSOS DE AMPARO. SEGÚN EL CONTENIDO

AÑO 2020

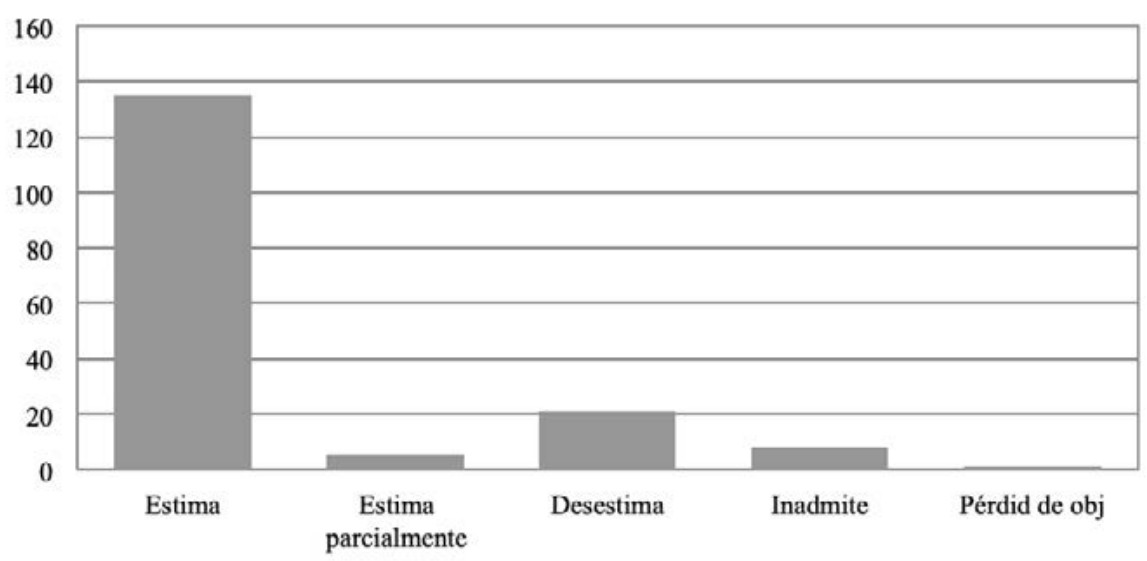

RECURSO DE AMPARO. DERECHO FUNDAMENTAL

ALEGADO. AÑO 2020

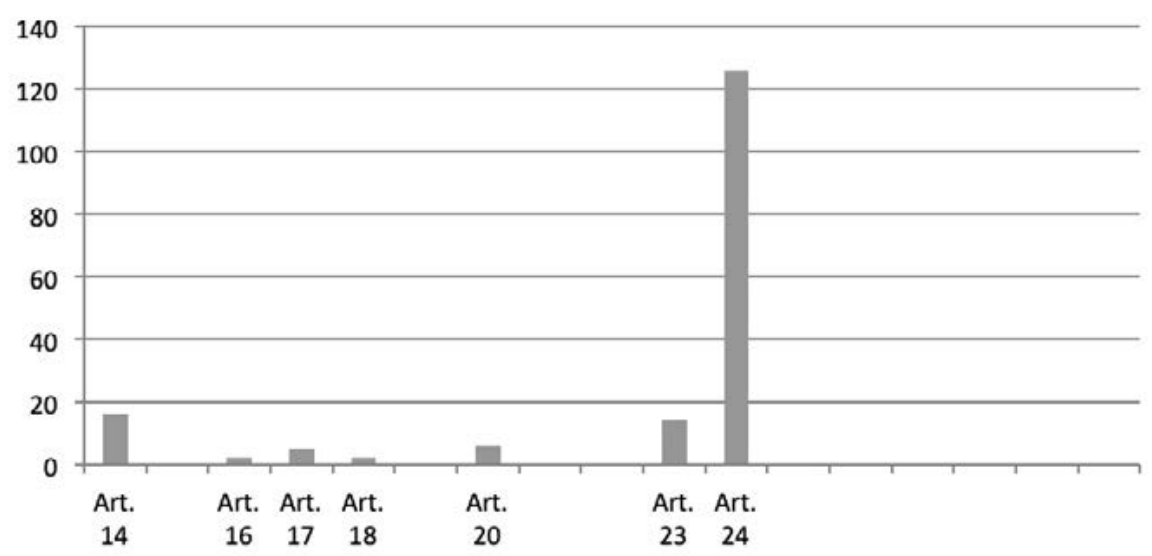




\section{RECURSOS DE AMPARO. ÓRGANO QUE DICTA LA RESOLUCIÓN RECURRIDA. AÑO 2020}

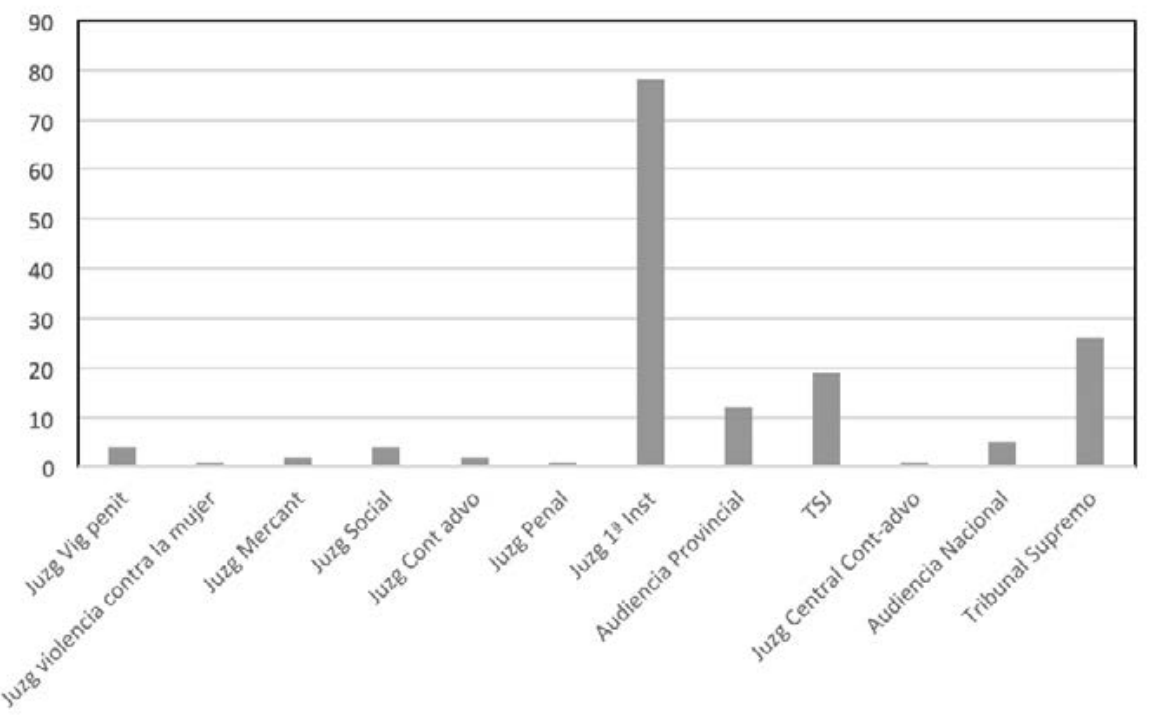

RECURSOS DE AMPARO. TIPO DE RESOLUCIÓN RECURRIDA.

AÑO 2020

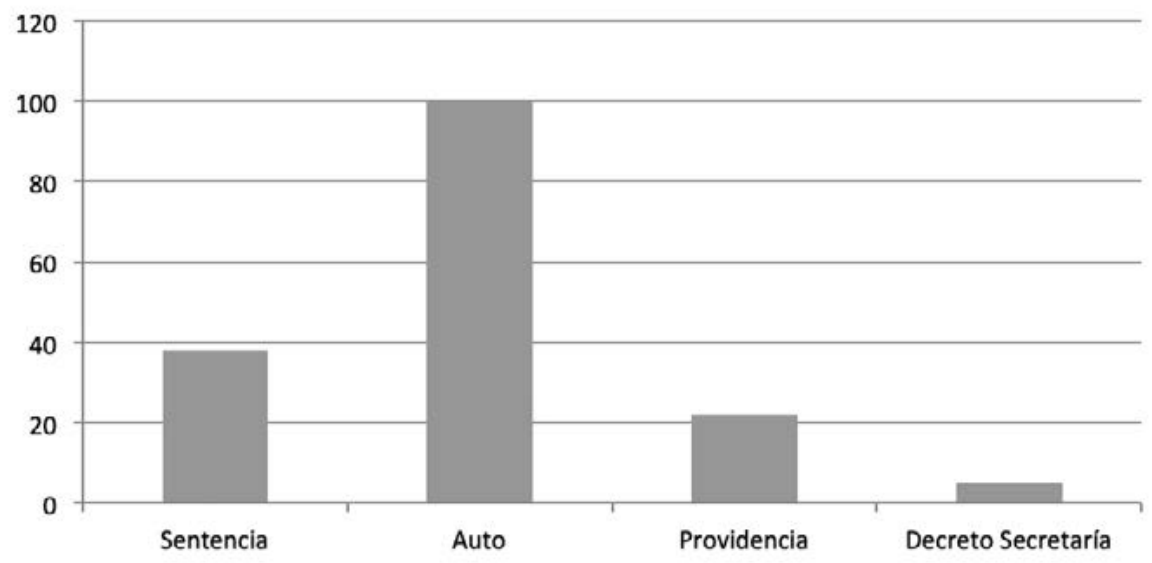


